\title{
Religion as a Protective Mechanism for Families Affected by HIVIAIDS
}

\author{
Sandlana N. S. \\ Majokweni 0. \\ Department of Psychology, University of Fort Hare, \\ Alice. 5700. Eastern Cape. South Africa, \\ E-mail: nsandlana@ufh.ac.za
}

\author{
Doi:10.5901/mjss.2013.v4n14p269
}

\begin{abstract}
The aim of the study was to investigate the role of the church in helping HIV and AIDS affected families cope with HIV and AIDS related challenges. A qualitative study was conducted using one-on-one semi structured interviews to gather information from HIV and AIDS affected families and church members, including church leaders. The findings revealed adequate knowledge of HIV and AIDS; prevention, transmission and treatment, however these families' perception about HIV and AIDS still has elements of stigma and discrimination. Not all churches take an active role in the struggle against HIV and AIDS. 50\% of the affected families reported that their churches were not fully participating, $20 \%$ not participating at all and $30 \%$ actively involved. The study revealed that amongst the churches which are not fully participating but aware of the existence of HIV and AIDS are Charismatic churches, such as, the Assemblies of God and the City of Light. HIVIAIDS affected families do not disclose at church because of fear of being stigmatised and discriminated against as HIVIAIDS is attributed to God's punishment for promiscuity. Furthermore, much as most church leaders and congregants are doing their best in helping the affected families, only three churches out of ten have got programmes put in place for helping the infected and affected families. These include workshops and home and hospital visits for both the affected families and infected church members.
\end{abstract}

Keywords: HIV, AIDS, religion, congregation

\section{Introduction}

Sub-Saharan Africa is more affected by Human Immunodeficiency Virus (HIV) and Acquired Immune Deficiency Syndrome (AIDS ) than any other region of the world. An estimated 22.5 million people are living with HIV in the region -around two thirds of the global total (HIV and AIDS in Africa, 2011). In 2009 around 1.3 million people died from AIDS in Sub-Saharan Africa and 1.8 million people became infected with HIV. The Eastern Cape AIDS Council was established in 2001 as an organ to coordinate and champion the response against the HIV and AIDS pandemic in the Eastern Cape Province.

After an HIV diagnosis most individuals and their families seek God and solace by going to church. However, previous studies reveal continuing stigmatisation and discrimination in many churches (Cichocki, 2010; Kumar, 2011; Senzanje, 2011), resulting in church members (especially those affected and infected by HIV) struggling to make sense of their faith in the light of HIV and AIDS (Senzanje, 2011). According to Gennrich (2007), church members believe that HIV and AIDS is a result of God's punishment for promiscuity. This makes the affected families feel marginalised, isolated, disempowered and enhances mistrust towards the church.

According to Okaalet and Happonen (as cited in Happonen, Jarvinen \& Virtanen, 2002), the church is in a unique position in Africa to address HIV and AIDS. Churches attract large crowds, meet regularly, and are active in health and education sector. Traditionally, religious leaders have not only dealt with the spiritual needs of the people, but also served as counsellors, psychologists, sociologists and healers. Therefore, churches and church leaders have a prominent role in African societies. This places churches in a privileged position to influence people's behaviour and attitudes, even in relation to the HIV pandemic (Okaalet \& Happonen as cited in Happonen et al., 2002). The status quo of churches is that they preach acceptance of people living with HIV and AIDS even though there is stigmatization and discrimination from the church leaders and congregants (Senzanje, 2011).

Dominic, Carone, and Barone (2001) postulate that some churches that get involved in helping the HIV and AIDS affected families engage in counselling, pastoral visits and support groups which are aimed at enhancing a psychological sense of community. These activities enhance acceptance and promote the affected families' understanding of their 
status and the world around them; they provide order to the chaotic and unpredictable world. The aim of this study was to explore the role of the church in helping HIV and AIDS affected families cope with HIV and AIDS related challenges.

\section{Methodology}

A naturalistic qualitative research was used to generate information and ideas regarding the churches' role in assisting the HIV and AIDS affected families in Alice. Semi- structured interviews were used because of the sensitive nature of the study to enable the researcher to gain insight into the problems of the affected family members. The population of this study included all the congregants of the ten churches in Alice (Anglican, Methodist, Uniting Presbyterian, Baptist, Corner Stone Christian church, Zion Christian Church, Assemblies of God, St. Johns, City of Light, and The Uniting Reformed Church). A purposive sampling was used to select thirty participants consisting of twenty HIV and AIDS affected family members, two from each of the ten churches, and also one leader, pastor or elder, from each church. Trends and patterns emerged from the collected data which ultimately led to themes which were displayed and verified.

\section{Discussion and Interpretation of Results}

Current literature makes reference to the challenges of eradicating HIV-related stigma and discrimination within churches and some analysts suggest that HIV- related stigma and discrimination are persistent within churches, but there are HIV and AIDS response activities that are currently growing rapidly. Themes that emerged from the data included knowledge and perception of HIVIAIDS, the role played by the church leaders and congregants towards HIV and AIDS affected families, and the strategies used by the HIV and AIDS affected families to deal with their HIV and AIDS related problems. The findings are discussed in detail below as follows:

\subsection{Knowledge of HIV and AIDS}

According to the AIDS Risk Reduction Model, as explained by UNAIDS (1999), the behaviour change process is based on three phases: knowledge about HIV transmission, perceived HIV susceptibility, as well as aversive emotions, influences how people view HIVIAIDS. The second phase is that of commitment shaped by four factors: perceptions of enjoyment, self efficacy, social norms and aversive emotions. The last phase is characterised by aversive emotions, sexual communication, help-seeking behaviour and social factors affecting people's decision-making process.

The participants' knowledge of HIV and AIDS encompasses their understanding of HIV and AIDS prevention, transmission and treatment.

\subsubsection{HIV/AIDS Prevention}

The affected families were more careful and understood the preventive measures that had to be taken because the families showed that they did not want to experience what their infected family members experienced. They were empowered through workshops and HIVIAIDS awareness campaigns that created more awareness and acceptance. Prevention is done at primary, secondary and tertiary level of prevention.

\subsubsection{Primary prevention}

The preventive measures are the HIV and AIDS education that the churches had and awareness campaigns. The church leaders also preached and educated the congregants about abstinence and mutual fidelity. The couples would be advised to go for HIV testing before they get into marriage. They were also educated on the use of condoms. As much as they are church members and noting abstinence as the most important prevention measure, they did not turn a blind eye to the fact that people are sexually active and the use of condoms is vital. They noted that abstinence and being faithful to one partner are important measures in preventing the increase of HIV infection. However, a reverend posited that culture has an impact on the transmission of HIV because one man can decide to have more one wife.

The other respondents noted that the use of gloves is important and if there are no gloves, one can use plastic to protect themselves from being infected when helping their loved ones or strangers. Lastly, the respondents also noted testing as a preventative measure whereby people test to find out as soon as possible what their statuses are so that the HIV infected individuals can prevent the disease at an early stage and for those who are not infected can protect them. 


\subsubsection{Secondary prevention}

According to Bandura's (1997) Social learning theory (SLT), HIVIAIDS affected families should learn a more adaptive and extensive range of coping skills from others. The church leaders and congregants advised the affected families to advise their infected family members to use condoms to protect themselves from further multiplication of the HIV infection. They advised mothers on how to protect their children from being infected and to avoid negative thoughts about themselves.

\subsubsection{Tertiary prevention}

The church leaders and congregants advised those HIV and AIDS affected members to make sure that their infected members do not consume alcohol and drugs. According to the Family Resilience Theory, as described by Walsh (2006), HIVIAIDS affected families use the church as their source of strength. They relate to the church's healing power of compassion and forgiveness.

\subsubsection{HIV and AIDS transmission}

Members of the affected families stated that HIV and AIDS are mostly transmitted through sexual intercourse between two sexually active individuals. They also stated that HIV is transmitted through blood transfusion whereby an individual would touch another person's blood in a car accident or when helping other people and both individuals have open wounds. One of the respondents stated that HIV transmission through open wounds usually happens when old people nurse their infected children because of their parental love instead of taking precautions. They were also aware of the mother to child transmission.

The affected family members indicated that they knew AIDS as an incurable disease that affected men and women of all ages, but mostly those who were sexually active. The other transmission takes place through body fluids such as semen. They also indicated that AIDS is a disease caused by a germ that is passed on from one person to another.

\subsubsection{HV and AIDS treatment}

This section focused on the medication that the infected individuals take as well as the manner in which they are taken care of by family members. The HIV and AIDS affected families knew the treatment taken by their infected family members. They mentioned that they monitor their family members' intake of antiretroviral treatment (ARV). Other respondents stated that ARVs are not really the treatment for the disease but something that decreases the multiplication of the virus in the body. Some affected family members stated that their family members take antibiotics depending on how much of the virus is in their body, and some drink vegetable water and herbal treatment to strengthen their bones. They also mentioned healthy eating habits: fresh vegetables and lots of protein to stay healthy.

The researcher saw that most of the respondents used alternative ways that also helps with the reduction of the HIV virus in the body. This is because some of the respondents' family members cannot afford the ARVs and they make sure that they use what they can afford to keep on being strong and healthy. One other respondent stated that her mother does not get too worried when she misses the exact time of taking medication, as she is able to take it thirty minutes after her regular time and still be healthy.

According to the family resilience theory, the family belief systems are at the core of family functioning. Family belief systems encompass values, attitudes, convictions, biases and assumptions (a set of basic premises that trigger emotional responses) which inform decisions and guide actions (Walsh, 2006). The church leaders and congregants who showed that they had factual knowledge about HIV and AIDS revealed that their stigmatization and discrimination attitude towards the affected families is reduced and their biblical values guide their action towards the HIV and AIDS affected families. For instance, a reverend explained that HIV and AIDS start with ones' personality whereby the individual outlines his or her values. The Bible states that one has to take care of his or her body and treat it like Gods temple. The participants that had little knowledge about HIV and AIDS revealed biases and discriminating attitudes towards the HIV and AIDS affected families because of denial and ignorance. 


\subsection{Role played by the church leaders and congregants}

The discussion on the role of churches in the fight against HIVIAIDS is divided into the following categories:

- Churches that do not assist HIVIAIDS affected families;

- Churches that help HIVIAIDS affected families occasionally; and

- Churches that provide assistance to HIVIAIDS affected families on a regular basis.

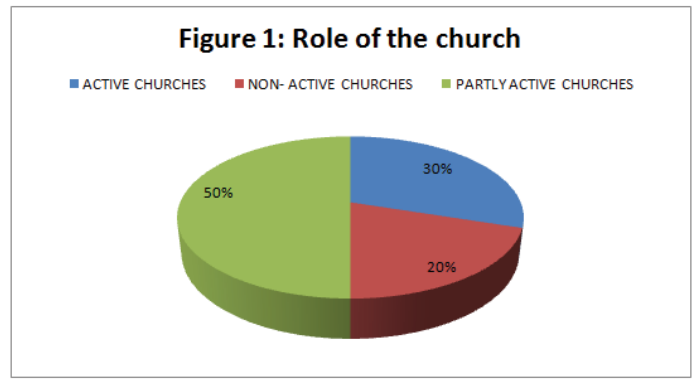

\subsubsection{Churches not assisting the HIV and AIDS affected families}

Two out of twenty HIV and AIDS affected family members pointed out that their churches are not involved in assisting them. The reasons given for the churches not being engaged in helping these affected families are that the families do not disclose about their HIV infected family members so the church is unaware of these HIV and AIDS affected families.

Another reason is that some churches see HIV and AIDS as a punishment from God and, therefore, infected people are living in disobedience to God on account of their immorality. Even though these churches reported to be doing nothing about HIVIAIDS, they revealed that whenever the words 'HIV' and 'AIDS' is mentioned behind the pulpit, it will be to just inform and warn the church members that HIV does exist and the youth not to be involved in sex before marriage. The reasons given above for churches not being involved in helping the HIV and AIDS affected families came from the one-on-one interviews. Two churches, namely, Assemblies of God and City of Light do not help the affected families.

The researcher recognized that these churches did not see HIV and AIDS as their responsibility but that of the schools and health departments. These churches are aware that there is HIV within their walls but they still stigmatise and discriminate against the affected families. Another aspect is that some of the church leaders do want to attempt the HIV and AIDS topic, but because of the attitude towards the disease it is difficult to do so.

The non- participatory churches' belief system shows that they still have elements of stigma and discrimination and are rigid towards the HIV and AIDS affected families. Overly rigid churches that provide either too much or too little structure may undermine family resilience (Walsh, 2006). They are still in denial because HIV and AIDS is a shameful disease to talk about. It is taken as a promotion of promiscuity especially within the youth.

According to Mackay (2003), communication is central to the process of meaning-making in families -- how family members perceive themselves and their relation with the outside world and how they make sense of the challenges they are facing -- as well as to the process of coping. The church leaders' and congregants' communication with the affected families is interrupted because there is no social interaction between them and the affected family members. Therefore, this attitude leads to affected families feeling isolated and discriminated against. Shisana (2004) further argues that the resulting shame leaves the individual with a feeling of being personally responsible for their consigned undesirable status.

According to Bandura's (1997) social learning theory, for an individual to be able to cope with adversity, one has to develop a strong connection with her/his social world. This has psychological impact on the family members such as depression, frustration and anxiety (William, 2011). The inability to cope is associated with the risk factors that increase the probability of negative outcomes (Mackay, 2003).

\subsubsection{Churches that help the HIVIAIDS affected families occasionally}

Ten out of twenty churches HIV and AIDS affected family members stated that their churches are involved but did not have specific programmes in place, such as including it in their year plan. The responses they made against HIV and 
AIDS was shown to be occasional and is done through inviting people from outside the church, such as people from the health professions. Most of these programmes are targeting youth and adults. The most visible activity done in this category is the prayer meetings done by the minister and the congregation for the affected family members. All the churches under this category do not have HIV and AIDS policies and they do not have HIV and AIDS projects in their year plan. The churches in this category are the Baptist Church, the Corner Stone Christian Church, Zion Christian Church, St. Johns and Uniting Reformed Church.

The researcher noticed that these churches are aware of the dangers of HIV and AIDS and some of them are in the process of having specific HIV and AIDS projects and programmes. However, there is still a challenge of addressing the pandemic within the church. Some of the church leaders and congregants are not entirely open about HIV and AIDS and there is still discrimination and stigma through their actions. There are church leaders who try to bring it up as an important issue but it becomes difficult to address HIV and AIDS because this put them at risk of unacceptance by the other leaders and congregants. The other challenge is that they do not have resources to have and sustain major HIV and AIDS projects and programmes.

The family resilience theory posits that effective communication is important in the development of a sense of shared decision-making, which is achieved through negotiation, compromise and reciprocity (Mackay, 2003). The HIV and AIDS affected families in this category can identify the church leaders who are open and exposed to HIV and AIDS related issues and communicate with them because not everybody is for HIV and AIDS. Strong relationships, cohesion, a better belief system may develop; effective communication and coping strategies may be available to help the affected families. This theory further states that protective factors interact with risk to change the predictive relationship between risk factors and negative outcomes, reducing the probability of negative outcomes (Mackay, 2003). The discrimination and stigma experienced by the family members may be reduced and they are able to cope better than those who are totally discriminated against and they are able to find better ways to cope with the HIV and AIDS adversity.

\subsubsection{Churches that provide assistance to HIV/AIDS affected families on a regular basis}

Eight out of twenty family members who participate in the study stated that their churches are involved in helping the HIV and AIDS affected members. The Anglican Church has been found to be one of the leading churches in helping the HIVIAID affected family members in Alice, and it offers services such as HIVIAIDS education, care-giving to children living with HIV and AIDS (Isibindi project), education about HIV and AIDS through presentations, manyano initiatives of donating food parcels and clothes to individuals at the Alice hospice and to the affected families. The other active churches are the Methodist Church and Uniting Presbyterian Church.

Church and the Uniting Presbyterian Church. They have fundraising from time to time and clothes donations for the HIV and AIDS affected families.

These churches have prayer meetings and home and hospital visits for the infected family members. They also conduct candlelight services, HIV and AIDS awareness campaigns and workshops. The HIV and AIDS education is offered to all members of the church, but the main target is the youth because they are the most vulnerable group. The emphasis of their teaching is on abstinence and faithfulness. The other option of using condoms is not considered in their teaching, but is replaced by teachings on behavioural change. In other words, if people can change their behaviour that makes them vulnerable to the HIV virus, condoms will not be necessary.

The researcher viewed these churches' activities as effective because they talk and preach about HIV and AIDS and put their words into action. The church has an impact when they put action to their work. The church leaders and congregants are able to emphasise and not only sympathise with the HIV and AIDS families. As a result the families are then able to fight their HIV and AIDS challenges less depressed and anxious and instead are confident in disclosing their family statuses because they know they are not discriminated against and stigmatised by the church leaders and congregants. These churches do not see themselves as isolated from the community but being part of it, and the affected families are aware that they can be assisted by the church.

The social cognitive theory explains how people acquire and maintain certain behavioral patterns, while also providing the basis for intervention strategies (Bandura, 1997). Evaluating behavioral change depends on the factors: environment, people and behavior. This theory communicates that the HIV and AIDS affected families are able to change their behaviour patterns when they have social support from the church leaders and congregants. Additionally, their coping strategies are able to be implemented because of the positive climate environment.

According to William (2011), resilient families tend to develop a flexible structure that balances strong leadership and the ability to maintain continuity in the face of adversity, alongside the adaptive capacity to accommodate to change. 
The HIV and AIDS affected families are able to face their HIV and AIDS challenges continuously and the church leaders have an important impact because they managed to educate the church congregants about HIV and AIDS and take action. The church leaders' belief system is positively structured because there is no discrimination and stigmatization against the affected families, instead there is action taken to alleviate their HIV and AIDS related problems. A protective factor is revealed through the support that the church associations show to the affected family members.

The majority of church leaders and congregations who noted that their churches help them occasionally and do not have strategies put in place, make use of prayer meetings as methods to overcome their HIV and AIDS related problems. The church leaders and congregations suggested strategies that the church should incorporate in dealing with or helping the affected families.

\section{HIVIAIDS church strategies}

The majority of church leaders and church members who noted that their churches help them occasionally and do not have strategies put in place, make use of prayer meetings as methods to overcome their HIV and AIDS related problems. The church leaders and congregation suggested strategies that the church should incorporate in dealing or helping the affected families. The suggested strategies are the establishment of partnership with local schools by the church leaders; the church should initiate awareness programmes at their churches.

\subsection{The establishment of partnership with the community and local schools}

The church leaders and congregants perceived their role as that of creating a partnership with local schools. They explained further that if changing peoples' behaviours were to be effective and have the required outcomes, the HIV and AIDS message should start at the earliest possible age; possibly at primary school level and Sunday schools, before the onset of sexual activity. The church leaders and congregants therefore have a responsibility to work in partnership with the schools to stop the spread of this disease. This implies that age-appropriate programmes could be started in primary schools and in churches on Sundays. Such programmes are structured to give the young ones the same information as given to the youth, but in a more appropriate manner. The HIV and AIDS affected families indicated that the church is a much respected institution in any community. It should not only focus on changing the behaviours of the youth and the young, but also entire communities, which include the aged and the adults.

The majority of the church leaders and congregants were of the view that the church should not only partner with the schools and the community, but also with the government and other people of good will to change individuals' risky behaviours and to combat HIVIAIDS. The researcher saw that as much as the church leaders and congregants wanted to establish partnership with the community and local school, they stated it is a difficult task in trying to work with the community because not everyone in the community will understand the educational perspective of the church. People have different belief systems and the church leaders and congregants will have difficulty in convincing for instance high school children how to abstain from sex. One of the reverend stated that children would make a comment such as " how possible is it for someone to eat a sweet with a wrapper on" meaning that the use of condoms is not important.

The observational learning beliefs are based on observing others and pointing out others' experience and physical visible changes; identify role models to follow and when people are educated about HIV and AIDS, they then can change their beliefs by observing from others (Heimann, 2003). The family resilience theory states that messages from religious leaders may also shape peoples' beliefs that could shape their attitudes.

\subsection{HIVIAIDS education}

The church leaders and congregants stated that they provide education to the church congregants as a primary preventive measure. The church educates the congregants and the other leaders by inviting people such as social workers, nurses and teachers on a regular basis to talk about HIV and AIDS. Through such education which takes place in the form of presentations, church association and workshops, the church members would be made aware of the different issues concerning HIV and AIDS. Some of the church leaders and congregations indicated, for instance, that they did not know the early or even later signs of HIV and through the educational programs all people who did not know the facts about HIV and AIDS were educated. According to the family resilience theory the support by church association serves as a protective factor.

The researcher noted that even though the church leaders and congregants organised the educational programs, 
the turnout of people was poor and it discouraged the leaders to host such events. One HIV and AIDS affected family member, who is an HIV and AIDS counsellor, stated that she once was a part of an HIV and AIDS educational program organised by her church and the turnout was very poor. One reverend stated that people are tired of hearing about HIV and AIDS, but they are not cautious and when they are infected they take time to accept and cope with the disease.

\subsection{Pastoral counselling}

The church members and congregants agreed that people affected by HIV and AIDS were often distressed, lonely and lacked self-esteem. The church leaders and congregants offered pastoral counselling to those who are affected by HIV and AIDS. The affected families are helped to grow, develop and understand their own lives through the scriptures. The church leaders and congregants who have the knowledge about HIV and AIDS and professionally dealt with the pandemic, offered counselling to the HIV and AIDS affected family members.

Pastoral counselling was not much of a challenge for the church leaders because it was part of their daily practice and they knew their congregants. The interviewed reverend stated that they made personal visits to pray with the HIV and AIDS affected families and spoke words of encouragement to the infected family members. However, in some families the infected members felt that prayers and medication did not work so they would consult with traditional healers and stop taking their medication. The parents would then invite the reverend to give the individual hope. The infected family members who were able to accept and had faith lived longer and those who did not accept in time were killed by fear.

The family resilience theory posits that individuals must possess positive adaptation under adverse circumstances. When the affected families adapted quicker to the changed situation of having an infected family member, they were able to cope with the challenge. A family can be considered resilient when it has encountered adversity and coped successfully with the challenge (Mackay, 2003). According to the social learning theory, the consequences of behaviour and cognition play a role in learning (Rice, 2000). The HIV and AIDS affected families can change their thinking about their statuses and counselling to have positive behaviour change.

\section{Recommendations}

The following recommendations arose from the interview:

\subsection{HIV/AIDS programmes}

Based on the responses of some family individuals, it was indicated that some church leaders could not help the HIV and AIDS affected families because of the church leaders and members' perceptions about HIV and AIDS. The discrimination and stigma still plays a role in changing church leaders and congregants' perceptions about HIV and AIDS. The stigma attached to AIDS causes families who are affected to remain silent about their status.

From the findings of this study, it came out from the participants that HIV and AIDS programmes should be established in every church by including it in their year plan programmes, just like the other programmes that they consider to be important. By including HIV and AIDS programmes in the year plan, the churches will be able to monitor the programmes as well as analyse their impact with ease. If the programmes are regular, it would be easy to make follow-ups on the progress of the programmes.

The researcher recommends that the Department of Health and the Nkonkobe Municipality include the training of church leaders in their programmes as well as in its Development Programme. The training can be taught to church leaders, youth leaders, women and men's groups and other forms of leadership. This can be done through group training sessions, enabling the participants to train others by distributing AIDS information, help others to accept the reality of AIDS and promote compassion and care for the afflicted (Machyo, 2011). Another recommendation is that church leaders should include HIV and AIDS training as one area of capacity building to enable them to deal with the HIV and AIDS pandemic from a position of strength. In this study, churches are dominant structures in the community with many people and if targeted as one of the tools to fight HIV and AIDS, the infection rate could drop.

\subsection{Partnership with the Department of Health and Non-governmental Organizations (NGOs)}

The researcher asserted that many of the participants who were found to be doing something to fight HIV and AIDS felt 
that the church leaders should seek partnership with the Department of Health and Non- governmental Organizations involved in the fight against HIV and AIDS in order to increase the church leaders and congregants' knowledge about HIV and AIDS. The other recommendation is that of accessing materials to help both the church leaders and congregants in equipping the church members to fight against HIV and AIDS. Some church members who gained knowledge on how to deal with HIV and AIDS from home-based care organizations desired to share their knowledge with the church, and this shows that such organizations are important. The partnership could also help the church in accessing the services of resourceful people who could be hosted in their churches with regard to awareness programmes in the churches.

\subsection{HIV and AIDS counseling and referrals by churches}

Most of the affected family members acknowledged that the church is not in the position to provide treatment to people living with HIV and AIDS, but can offer help in the area of counselling and referrals for the affected members. This would enable them to be able to support their HIV positive family members. The referrals will also help the members of churches who do not have the knowledge of HIV and AIDS, for example encouraging members with health problems to go for voluntary counselling and testing to know about their HIV and AIDS status in order to make informed decisions in the fight against HIV and AIDS.

\subsection{Continuous elimination of discrimination and stigma}

The church must take a lead in discouraging discrimination since the love of God is unconditional, that is, every believer was saved by the grace of God. The people in the community should learn from the church to love unconditionally as this is the basic principle of church life. The church should advocate for the affected families on behalf of their HIV infected families to all institutions that need to be involved, instead of discriminating and stigmatising them. The teaching of the church is obliged to re- examine the consistency and creditability of messages it communicates in both words and practice (Machyo, 2011).

\section{Conclusions}

In this study, the researcher set out to explore the manner in which the church influences the coping methods or mechanisms of the HIV and AIDS affected families. She investigated the way in which families affected by HIV and AIDS understand the knowledge of HIV and AIDS. The researcher also examined the role played by church leaders and congregants in relation to HIV and AIDS challenges faced by affected families. And lastly, the researcher identified strategies that enable these families to deal with their HIV and AIDS related problems.

The researcher found that the HIV and AIDS affected families have adequate knowledge about HIV and AIDS. Secondly, the majority of the churches are involved in assisting the HIV and AIDS affected families in Alice, however, there is more work that has to be done to understand why churches must develop loving and supportive attitudes toward those affected by HIV and AIDS, as well as a constructive and responsible approach to the public health/prevention agenda (Gennrich, 2007). The researcher also found that the churches do know about HIV and AIDS and they pray about HIV and AIDS, but there are no strategies put in place for special attendance to HIV and AIDS related issues.

The main question addressed the church assistance offered to the affected families in coping with HIV and AIDS. It was argued that the church, as an influential institution, in the community had an important role to play with regard to containing the spread of HIV and AIDS. This means that churches have to ensure that their members know what HIV and AIDS is, how it is spread and how to contain it. They must also ensure that all church members are familiar with the different HIV and AIDS related issues, including how to look after, give love and care to those affected. The researcher argued that how the churches responded to the different issues concerning HIV and AIDS depended on their views or perceptions on these issues.

\section{References}

Bandura, A. (1997). Self-efficacy: The exercise of control. New York: W.H. Freeman.

Cichocki, R. N. M. (2010). The role of Religion and Spirituality in HIV. Retrieved from http://aids.about.com/od/spirituality/a/religion 2.htm.

Dominic, A., Carone, A., \& Barone, D.F. (2001).A Social Cognitive Perspective. Journal of HIVIAIDS and Social Services, 8(3), pp. 238- 
250.

Gennrich, D. (2007). The Church in an HIV + World. Kwa Zulu Natal: Cluster Publications.

Happonen, H., Jarvinen, T. \& Virtanen, J. (2002).Towards an HIV and AIDS Competent Church. Finland: CUAHA networks and Tumaini University Publications.

Heimann, D. (2003). AIDS Risk Reduction Model (ARRM). Retrieved from http://www.sciencedirect.com/science/article/pii /S1054139X05006968

HIV and AIDS in Africa. (2011). Retrieved from http://www.avert.org/aids-hiv-africa.htm

Kumar, T. H. (2011). HIV Related Stigma, Discrimination and Human Rights Violation. Journal of HIVIAIDS Attitudes, (4) 2, pp. 4- 10.

Machyo, C. N. (2011). The Catholic Church and the HIVIAIDS Pandemic in Kenya: An Exploration of Issues. Retrieved from http://www.fiuc.org/iaup/esap/publications/cuea/eajourn1aidsch.php

Mackay, R. (2003). Family Resilience and Good Child Outcomes. Journal of New Zealand TePunaWhakaaro, (20) 1, pp. 2-4.

Rice, V. H. (2000). Handbook of Stress, Coping, and Health. London: International Educational and Professional Publisher.

Senzanje, N. (2011). Factors that contribute to HIV-related stigma and discrimination within the Christian faith community: a survey of the Christ Embassy Church in Windhoek. (Masters' thesis, The University of Stellenbosch University). Retrieved from http://scholar.sun.ac.za/bitstream/handle/10019.1/6675/senzanje factors 2011.pdf?sequence=2

Shisana, O. (2004). Why study stigma in South Africa? Stigma Project. Cape Town: SAHA.

UNAIDS. (1999). Sexual behavioural change for HIV: Where have theories taken us? Switzerland: UNAIDS Publications.

UNAIDS. (2005). HIV and AIDS related stigmatization, discrimination and denial: forms, contexts and determinants. Switzerland: UNAIDS Publications.

Walsh, F. (2006). Normal Family Processes: Growing Diversity and Complexity. London: The Guilford Press.

William, R., S. (2011). Mechanisms of Risk and Resilience in Military Families: Theoretical and Empirical Basis of a Family-Focused Resilience Enhancement Program. Journal of Medicine National Institution, (14)3, pp. 213-230. 
